$\begin{array}{lll}\text { Volume } 17 & \text { February } 1954 & \text { No. } 11\end{array}$

\author{
Original \\ From the Third Medical Clinic of Kysto University (Director: Professor M. Maekawa, M. D.) \\ Analytical Study of the Lymphon-Allergy III \\ BY \\ RYOHEI ICHIHARA \\ (Received for Publication, Oct. 22, 1950)

\begin{abstract}
淋巴腺ホスファテイドを以てせる淋巴球系アレルギー（リンホン・アレルギー 〔前川〕）の分析的研究
\end{abstract} \\ 第 3 報 自然牛血淸或は卵蛋白と淋巴腺ホスファテイドとに依るリンホン・アレルギー \\ の分析 其の一 \\ 醫 學士 市原 亮 平

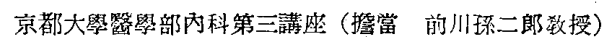

Rabbits were sensitized with the ox sera. After 3 weeks, those in group III were injected with the lymphnode phosphatide alone, while those in group IV with the mixture of egg-white-solution and lymphnode phosphatide. These groups failed to produce “Lymphon-Allergy." Following injection (the 2nd reinjection) of the mixture of ox serum and lymphnode phosphatide which was given 2 days after the 1st reinjection, gave rise to "Lymphon-Allergy". 3 weeks after the 2nd reinjection, III group were reinjected (third reinjection) with the mixture of ox serum and lymphnode phosphatide, while IV group were reinjected. (the third reinjection) with the mixture of egg-whitesolution and lymphnode phosphatide. The "LymphonAllergy" resulted in both groups.

These results suggests that lymphnode phosphatide alone does not produce "Lymphon-Allergy" and that

\section{緒論}

Rnsenau \& Anderson 1 ) は馬血清の $10^{-6} \mathrm{cc}$. (約 $7 \times 10^{-8} \mathrm{~g}$ 蛋白)でも海猽を感作し得ることを發見し，Wells 2) は結 晶卵アルブミンの $5 \times 10^{-8} \mathrm{~g}$. で小海猽の一定感作を得 た.Boyd?゙依れば，これらの量はこの方向に於ける 限度を代表するものである：致死的なショックを起すよ ，亏に十分感作するには更に大きい量を必要々する. 實際 の實驗には標準量として馬血淸の $0.01 \mathrm{cc}$. (約 $0.001 \mathrm{~g}$. 蛋 白）の 1 回量を皮下に淮射せられる. しかし乍ら量が餘 りにも大きいならば，特にそれが繰り返えしてなされる 場合は，動物は，或る場合には數週間も，ショック量の the substance used for reinjection as transporters must be the same one with that used for sensitization.

In group II treatment has been performed as follows: Sensitization with ox serum; after 3 weeks the 1 streinjection with ox serum; after 2 days the 2 nd reinjection with lymphnode phosphatide plus ox serum; after 3 weeks the third reinjection, with lymphnode phosphatide plus ox serum. After the 1st reinjection, no "Lymphon-Allergy" occurred. After the 2nd reinjection, no "Lymphon-Allergy" occurred.

After the 3rd reinjection, "Lymphon-Allergy" took place. Above results obtained in group II, III and IV render the conclusion possible that rabbits sensitized with ox sera can be desensitized with the injection of ox serum, but not with injection of lymphnode phosphatide alone or the mixture of egg-whitesolution and lymphnode phosphatide.

効果から防護される。これは多分，動物が事實上脫感作 されるように循環中に抗原が絕えずある鹪である5．家 鬼，大，猫の如き動物に於ては海猽に用いられた量より も大量が良く，家東に於ては海猽に十分であつたような 少量では全く無効である。潜伏期の因子が重要である.

異程血清の約 $0.01 \mathrm{cc}$. の標準量では, 海犋は 8 日頃に過 敏となり始め, 感作は 3 週間にして最高に達する. 繰り 返光し注射された家乘於ては 10 日乃至 3 週の間隔が アナフイラキシーを誘發しようと試みる前に時を經過せ

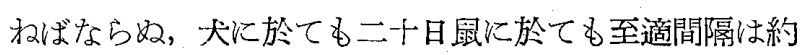
3 週間であると.Seegal \) は好適な感作方式として家鬼 
442

に於ては，1回の注射量血清を $0.2 〜 1$ cc., 1〜3 日の間 隔で 3〜8 回四注射を行い, 最終注射後 5 日〜2週間の潜 伏期の後，1〜3cc．の量を靜胍內に入れることを擧げて

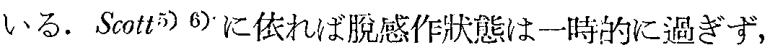
海猽に於ては 2 週或はそれ以上持緽し，家東ではもつと 短期間である。その後動物は同樣に或は以上に過敏にな る. 特殊な脫感作につづく抵抗打をもつ狀態の來る理由 は組織抗體が抗原によつて一時的に飽和されるのである と考克られ，それ以上抗原を入れても何にも起らない。 通常，脫感作狀態を特異的に招來するためには，ショッ クを誘發せぬ程度の微量の感作原を數㔷非經口的に投與 するのである。しかし Schultz-Dale7)8の方法に於ける が如く，大量抗原の再處置法により生體內の抗體を一時 殆んぞ全く消失せしめることもある. Friedber ger und Mita ${ }^{9}$ は稀釋した抗原を極めて徐々に注射して除感作し 得たことを認め，Wells10) は甽白アルブミンを經口的に 投與してそれに對する㓴敏症を除き得たと報じた，脱感 作には完全な場合と不完全な場合とあり，脱感作される 瑟度は感作に使朋せらるる抗原の量によつても左右され る.Weil 11) は感作に使用せる抗原の量が大なる場合に は，小なる場合よりも多感作に多星の抗原を装すること を貫驗し，それは，大量の揞原にて感作する場合には崖 生される抗體の量多きが故にその抗體を飽和するに比較 的大量の抗原を管するに因ると解䆁した，以上の如き特 暴抗原による脫感作の外に，他の抗原性物質を注射する ときショックの登現が抑剕されることを認め, Tillet, Anery and Goebel ${ }^{12}$ ) は念水崖素と蛋白質とを人工的に結 合せ乙めた物質を以て感作せる海㺍に對し，その含水琵 素成分のみを再注射に先んじて注射する場合にもショッ クの発現が抑制されることを擎察した。服部・熊谷1の 赤血球ホスファテイドと牛血㚋とを人工的に結合せしめ たものを以つて感作せる家禹に對し，その赤血球ホスフ アテイドのみを以て, 赤血球「ホ」加牛血清の西注射に 先んじて注射することにより、ショックの發現は抑制さ れなからたが苏血球系の組織アレルギー（エリトロン。 アレルギー) が抑制されるのを認めた。 ショックに於け

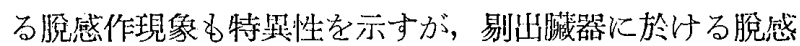
作現象が遥かに銳敏に特異性を示すことは諸家の實噞に ようて明かにされている。宮田 ${ }^{14)}$ は晹管反應の脱感作 現象に於て，人·牛・山羊の乳汁の特異性を研究し，牛乳 にて感作せる海猽の腸管に先ず山羊乳を注加すれば著明 な收縮反應がおこり，次で牛乳を注加すれば两び反應を 起し，山羊乳によつて不完全に脫感作されることを見， 同樣に牛乳にて感作せるものに先ず人㓡学遮朋するも何 等收縮反應を星せず，次で牛乳を注加せる場合に著明な 收縮反礁が括きている，即ち人乳によつては全く除感作 されなからたことが看取されるのである。

著者は第 1 報第 2 報に於て，牛血清によつて感作され たものが牛血淸にて殆えど完全に脱感作されるのを見た が，牛血清にて感作したものが淋巴腺ホスファテイドの

\section{第 17 然 第 11 號}

みによりて脫感作され得るや，更に牛血清にて感作した ものが淋巴腺「ホ」加畉蛋白によつて脫感作さるるや否 やを見んとした。文牛血淸にて感作し，再注射に淋巴腺 「ホ」加牛血清を以てすればリンホン・アレルギーを萑 起するが，再注射に牛血清のみを注射したのではリンホ ン・アレルギーが惹起されないのを第 1 報第 2 報にて報 告したが，然らば牛血清にて感作した家㭸群に淋巴腺ホ スファテイドのみを再注射したのでは惹起さるるや否 や，文平注射に淋巴腺「木」加牛血清の代りに淋巴腺

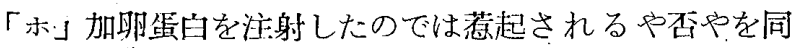
時に實驗せんとした。

\section{實 驗 方 法}

實驗動物は雄性家鬼 4 匹妾用い，第 1 報に於て述べた と同樣の注意の下に飼育した。先ず末梢血について塗深 乾燥固定染色標本を主として觀察し，特に淋巴球像を明 細に檢索し，更に白血球數，白血球百分比及び其の各々 の實數, 赤血球數, 血色素值を經過安追うて計算した。 實驗群については第 1 報第 2 報に於て述べたのを同時に 欢に表示する，本報に於ては其の第吕群第血群について 述べる.

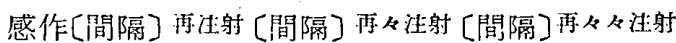

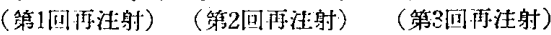

\begin{tabular}{|c|c|c|c|}
\hline 第 I 群 & $\mathrm{S}[3$ 週間] $\mathrm{P}+\mathrm{S}$ & & -- \\
\hline 政 群 & $S[\|]$ & $\mathrm{P}+\mathrm{S}$ [3週間] & $\mathrm{P}+\mathrm{S}$ \\
\hline ill & $\mathrm{S}[\|]$ & $\mathrm{P}+\mathrm{S}[\|]$ & $P+S$ \\
\hline ; 群 群 & $\mathrm{S}["] \mathrm{P}+\mathrm{E}["]$ & $\mathrm{P}+\mathrm{S}[\|]$ & $\mathrm{P}+\mathrm{E}$ \\
\hline
\end{tabular}

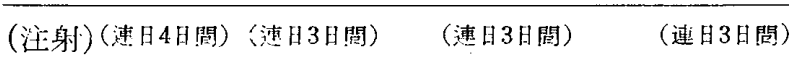

$\mathrm{S}$ : 牛血清, $\mathrm{P}+\mathrm{S}$ : 淋巴腺「木」加牛血清,

$\mathrm{P}+\mathrm{E}$ : 淋巴腺「木」加卵蛋白, $\mathrm{P}$ ：淋巴腺「ホ」,

注射液の製法：卵蛋白 (E) 及び淋巴腺「木」加卵蛋白 $(\mathrm{P}+\mathrm{E})$ 一一鷄卵の卵款をアルコールにて十分に垌拭し， 滅菌固體に打ちつけて割り，鶏卵の卵黄を去りて，1個 の卵白に無菌生理的食籃水を卯白量の約 3 分の 2 加光十 分に攪抖し，滅菌ガーゼ 8 枚にて漉過(約 2 時間を要す)

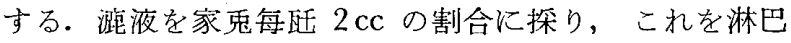
腺ホスファテイド酒精溶液とェムルジオンを作るが，こ の際酒精をアルコール臭なきまで溫槽中に蒸發し，生理 的食監水 $0.5 \mathrm{cc}$ 老加えて豫め稀釋し置き，その上に卵蛋 白生理食監水溶液を滴加振盓しつつエムルジオンを作り 約 1 時間室溫に放羁する.これを $\mathrm{P}+\mathrm{E}$ と略記する。そ の他の注射夜の製法恃第 1 報に於て逝べたと同梯で岕 る.

檢血方法も前報に於て逝べたると同樣である.

\section{實 驗 成 績}

1 . 體重・體湿・尿：第正群，第听群共に全經渦を通 じて體恶に著戀はない，體溫子特に變動したとは考光難 い. 尿では一過性に蛋白が陽性又は疑陽性に出るこるも あるが，すぐ恢復する.ウロビリうーゲンは全動物，全 經過を通じて陰性である.ヂアゾ反應も同樣に陰性であ 
TABLE 8 (3rd Group)

\begin{tabular}{|c|c|c|c|c|c|c|c|c|c|}
\hline & & No. & $\begin{array}{c}\text { Before } \\
\text { Sensitiz. }\end{array}$ & $\begin{array}{c}\text { After } \\
\text { Sensitiz. }\end{array}$ & $\begin{array}{c}\text { Before } \\
\text { 1st. Reinj. }\end{array}$ & $\begin{array}{c}\text { After } \\
\text { 1st. Reinj. }\end{array}$ & $\begin{array}{c}\text { After } \\
\text { 2nd. Reinj }\end{array}$ & $\begin{array}{c}\text { Before } \\
\text { 3rd. Reinj }\end{array}$ & $\begin{array}{l}\text { After } \\
\text { 3rd. Reinj. }\end{array}$ \\
\hline \multirow{2}{*}{\multicolumn{2}{|c|}{ Weight }} & 457 & $2.0 \mathrm{~kg}$ & $2.1 \mathrm{~kg}$ & $1.7 \mathrm{~kg}$ & $1.7 \mathrm{~kg}$ & $1.7 \mathrm{~kg}$ & $1.8 \mathrm{~kg}$ & $1.8 \mathrm{~kg}$ \\
\hline & & 460 & $1.7 \mathrm{~kg}$ & $1.8 \mathrm{~kg}$ & $1.6 \mathrm{~kg}$ & $1.6 \mathrm{~kg}$ & $1.7 \mathrm{~kg}$ & $1.7 \mathrm{~kg}$ & $1.7 \mathrm{~kg}$ \\
\hline \multirow{2}{*}{\multicolumn{2}{|c|}{ Temperature }} & 457 & $38.2^{\circ} \mathrm{G}$ & $39.1^{\circ} \mathrm{C}$ & $38.7^{\circ} \mathrm{G}$ & $38.7^{\circ} \mathrm{G}$ & $\angle 8.7^{\circ} \mathrm{C}$ & $39.0^{\circ} \mathrm{C}$ & $39.1^{\circ} \mathrm{G}$ \\
\hline & & 460 & $38.6^{\circ} \mathrm{C}$ & $38.2^{\circ} \mathrm{C}$ & $38.6^{\circ} \mathrm{G}$ & $38.5^{\circ} \mathrm{C}$ & $38.4^{\circ} \mathrm{G}$ & $39.0^{\circ} \mathrm{C}$ & $39.4^{\circ} \mathrm{C}$ \\
\hline \multirow{6}{*}{ Urine } & \multirow{2}{*}{ Albumin } & 457 & $(-)$ & $(-)$ & $(+)$ & $( \pm)$ & $(-)$ & $(-)$ & $(-)$ \\
\hline & & 460 & $(-)$ & $(-)$ & $(-)$ & $(i)$ & $(-)$ & $(-)$ & $(-)$ \\
\hline & \multirow{2}{*}{ Urobilinogen } & 457 & (-) & $(-)$ & $(-)$ & $(-)$ & $(-)$ & $(-)$ & $(-)$ \\
\hline & & 460 & $(-)$ & $(-)$ & $(-)$ & $(-)$ & $(-)$ & $(-)$ & $(-)$ \\
\hline & \multirow{2}{*}{ Diazoreaction } & 457 & $(-)$ & $(-)$ & $(-)$ & $(-)$ & $x$ & $(-)$ & $(-)$ \\
\hline & & 460 & $(-)$ & $(-)$ & $(-)$ & $(-)$ & $x$ & $(-)$ & $(-)$ \\
\hline
\end{tabular}

$\times$ not examined because the volume of the urine was not enough.

Table 9 (4th Group)

\begin{tabular}{|c|c|c|c|c|c|c|c|}
\hline & & No. & $\begin{array}{c}\text { Before } \\
\text { Sensitiz. }\end{array}$ & $\begin{array}{l}\text { After } \\
\text { Sensitiz. }\end{array}$ & $\begin{array}{c}\text { Before } \\
\text { 1st. Reinj. }\end{array}$ & $\begin{array}{c}\text { After } \\
\text { 1st. Reinj. }\end{array}$ & $\begin{array}{c}\text { After } \\
\text { 2nd. Reinj. }\end{array}$ \\
\hline \multirow{2}{*}{\multicolumn{2}{|c|}{ Weight }} & 458 & $1.7 \mathrm{~kg}$ & $1.8 \mathrm{~kg}$ & $1.7 \mathrm{~kg}$ & $1.7 \mathrm{~kg}$ & $1.7 \mathrm{~kg}$ \\
\hline & & 461 & $2.2 \mathrm{~kg}$ & $2.3 \mathrm{~kg}$ & $2.0 \mathrm{~kg}$ & $2.0 \mathrm{~kg}$ & $2.1 \mathrm{~kg}$ \\
\hline \multirow{2}{*}{\multicolumn{2}{|c|}{ Temperature }} & 458 & $39.2^{\circ} \mathrm{C}$ & $39.0^{\circ} \mathrm{C}$ & $33.2^{\circ} \mathrm{G}$ & $38.7^{\circ} \mathrm{C}$ & $39.5^{\circ} \mathrm{C}$ \\
\hline & & 461 & $38.6^{\circ} \mathrm{C}$ & $39.1^{\circ} \mathrm{G}$ & $38.7^{\circ} \mathrm{C}$ & $39.0^{\circ} \mathrm{C}$ & $33.2^{\circ} \mathrm{C}$ \\
\hline \multirow{6}{*}{ Urine } & \multirow{2}{*}{ Albumin } & 458 & $(-)$ & $(-)$ & $(-)$ & $(-)$ & $( \pm)$ \\
\hline & & 411 & $(+)$ & $(-)$ & $(-)$ & $(-)$ & $(-)$ \\
\hline & \multirow{2}{*}{ Urobilinogen } & 458 & $(-)$ & $(-)$ & $(-)$ & $(-)$ & $(-)$ \\
\hline & & 461 & $(-)$ & $(-)$ & $(--)$ & $(-)$ & $(-)$ \\
\hline & \multirow{2}{*}{ Diazoreaction } & 458 & $(-)$ & $(-)$ & $(-)$ & $(-)$ & $x$ \\
\hline & & 461 & $(-)$ & $(-)$ & $(-)$ & $(-)$ & $(-)$ \\
\hline
\end{tabular}

$x$ not examined because the volume of the urine was not enough.

る, 然し, ヂアゾ反應には尿量が相當量必要にして, ぞ うしても十分な尿量を探取出來ないで終つたものもあ る，これは表中に×印にて示してある. (TAR.8，TAP.9)

\section{2. 血液學的所見}

第正群：(No.457, No. 460)

(S $\quad \mathrm{P} \quad \mathrm{P}+\mathrm{S} \quad \mathrm{P}+\mathrm{S})$

No. 457 に就いて述ぶれば，牛血清の連日 4 日間の感 作では幼若淋巴球，淋巴芽球の出現を見ない，再注射に 淋巴腺ホスファテイドのみを連日 3 日間注射せる後第 2 日にその時の白血球數 7,900の2\%の幼若淋巴球を見る に過ぎない，然るに々の再注射終了後 2 日をおいて淋巴 腺「木」加手血清の再注射を連續 3 日間再々注射（第 2 回耐注射)するに，注射後第 1 日に幼若淋巴球はその時 の白血球數 4,700の $4.0 \%$ \%出現し，淋巴芽球は $1.0 \%$ \%出 現する, 第 2 日には幼若淋巴球は 8,400 の $11.0 \%$, 淋巴 芽球は $3.5 \%$ に出現する, 第3 日には幼若淋巴球は 12,900 の $12.5 \%$ ，淋巴芽球は $2.5 \%$ 出現し，淋巴芽球の變性像 も認められる，即ち第２回再注射後に於てリンホン・ア レルギーの萑起せられたのを見る. 更に第 2 回玨注射後 3 週間の後，第 3 回雨注射前檢血するに幼若淋巴球保僅 かにその時の自血球數 4,400 の $0.5 \%$ 現われるに過ぎず, 淋巴芽球はみとめられず，次いで同じく淋巴腺「ホ」加 牛血清にて連續 3 日間再々々注射（第 3 回再注射）を行 に，その注射後第 1 日幼若淋巴球はその時の日血球數 $4,200 の 7.5 \%$ ，淋巴芽球は $0.5 \%$ 出現し，第 2 日幼若 淋巴球は 4,400の $9.0 \%$ ，淋巴芽球は $2.0 \%$ 出現し; 第 3
日幼若淋巴球小 6,100の5.5\%に出現し，戀泩淋巴球も 現われて，第 3 回再注射後りンホン・アレルギーの惹起 せるのを見る。

No. 460 に就いて述ぶれば，牛血清連日 4 日間の感作 飞て感作後劥若淋巴球は之の時の血球數 9,300の 1.5 \%に出現するが淋巴芽球の红現は見ない。淋巴腺「木」 の久を速日 3 日間再注射した彴第 2 日にその時の白血球 數の僅かに $0.5 \%$ 幼若淋巴球が出現するのみで淋巴芽 球の出現はみない. 然るに淋巴腺「木」加牛血清の連日 3 日間の再々注射（第 2 回再注射）を行光ば，注身後第 1 日幼若淋巴球はその時の白血球數 5,000 の $6.5 \%$ ，淋巴 芽球は $1.0 \%$ 出現 し，第 2 日幼若淋巴球は 6,700 の 1.8 $\%$ ，淋巴芽球は $3.0 \%$ 出現し，第 3 日幼若淋巴球は 17,800 の $13.5 \%$ ，淋巴芽球は $3.0 \%$ 出現し，變性淋巴芽球飞出 現する.No. 457 と同樣に第 2 国胜注射後リンホン・ア レルギーが惹起される. 更に同じく䉼区腺「木」加牛血

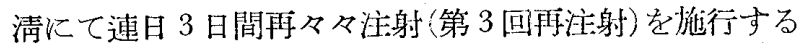
に，注射前以幼若淋巴球も淋巴芽球も出現を見なかつた が注射後第 1 日幼若淋巴球はその時の白血球數 4,100の $8.0 \%$ ，淋巴芽球は $1.0 \%$ に出現し，第 2 日幼若淋巴球は 4,200 の $7.0 \%$ ，第3 日は 5,800の $4.5 \%$ 出現している。 この際第 2 日，第 3 日には淋巴芽球は出現していなから た。即ら第 3 回再注射啳に於てもリンホン・アレルギー の惹起して居るのを認めた.

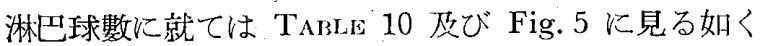
牛血清の感作，淋区腺「木」の再注射にては特に霄加す 
ることもなく，淋巴腺「木」加牛血清の再々注射によつ ては，No. 450 は著明な淋巴球橧多症を呈し，No. 457 で は餘り明滕でない，淋巴腺「木」加牛血清の再々久注射 では兩例とも相對性增多を認められる. Fig. 5 の下段は 幼若淋巴球及び淋巴芽球の出現率を示するのである.

淋巴球系以外の白血球について述ぶれば䅉好酸球，好 酸球，好覧基球，單球には著變なく，形質細胞は No. 457 に於て再及久注射後第 2 日目に $1.0 \%$ ，No. 460 に 於て再及注射後第 1 日目に $0.5 \%$ 出現した。 有核赤血球 は出現せず，兩例とも再々注射及び再々及注射後多染性 赤血球が輕度に出現したに止まる. 赤血球數，血色素値 共に感作後, 再乃注射及び再々タ注射後輕度に減少する
傾向があるのみである.

第血碃：(No.458, No.461)

$$
\text { ( } \mathrm{S} \quad \mathrm{P}+\mathrm{E} \quad \mathrm{P}+\mathrm{S} \quad \mathrm{P}+\mathrm{E})
$$

No. 458 について述ぶれば，牛血清の連日 4 日間の感 作後乞の時の白血球數 4,800 の $1.0 \%$ 亿幼若淋巴球が出 現するの及にして，再注射前には出現しない。淋巴腺 「木」加畉蛋白の連日 3 日間の再注射によつて，注射終 了後第 1 日その時の白血球數 4,200 の $0.5 \%$ ，第 2 日 5,300 の $3.5 \%$ \%幼若淋巴球が出現するが, 淋巴芽球の出 現はみられない，然るに，その第 1 回再注射後 2 日を和 いて淋巴腺「木」加牛血清の連日 3 日間の再注射を行う に，注射後第 1 日 4,200 の $16.5 \%$ の幼若淋巴球， $2 \%$ の

TABLE 10 (3rd Group)

\begin{tabular}{|c|c|c|c|c|c|c|c|c|c|c|}
\hline No. & & $\mid \mathrm{Hb}$ & $\mathrm{E}$ & $\mathrm{W}$ & $\mathrm{My}$ & Mon & $\mathrm{Pl}$ & Ly & JLy & Lybl \\
\hline \multirow{12}{*}{457} & $\begin{array}{c}\text { Before } \\
\text { Sensitization }\end{array}$ & $77 \%$ & 600 & 7,400 & $3,959(53.5 \%)$ & $481(6.5 \%)$ & 0 & $2,960(40.0 \%)$ & 0 & 0 \\
\hline & $\begin{array}{c}\text { After } \\
\text { Sensitization }\end{array}$ & $62 \%$ & 483 & 9,500 & $3,325(35.0 \%)$ & $47(0.5 \%)$ & 0 . & $6,128(64.5 \%)$ & 0 & 0 \\
\hline & $\begin{array}{c}\text { Before } \\
\text { 1st. Reinject. }\end{array}$ & $60 \%$ & 452 & 10,100 & $3,182(31.5 \%)$ & $201(2.0 \%)$ & 0 & $6,717(66.5 \%)$ & 0 & 0 \\
\hline & $\begin{array}{c}1 \text { Day } \\
\text { After } 1 \text { st. } \mathrm{R} \text {. }\end{array}$ & $61 \%$ & 475 & 6,400 & $2,432(38.0 \%)$ & $32(0.5 \%)$ & 0 & $3,936(61.5 \%)$ & 0 & 0 \\
\hline & $\begin{array}{c}2 \text { Days } \\
\text { After 1st. R. }\end{array}$ & $63 \%$ & 539 & 7,900 & $3,042(38.5 \%)$ & $276(3.5 \%)$ & 0 & $4,582(58.0 \%)$ & $158(2.0 \%)$ & 0 \\
\hline & $\begin{array}{r}\text { l Day } \\
\text { After 2nd. R. }\end{array}$ & $58 \%$ & 406 & 4,700 & $1,622(34.5 \%)$ & $70(1.5 \%)$ & 0 & $3,008(64.0 \%)$ & $188(4.0 \%)$ & $47(1.0 \%)$ \\
\hline & $\begin{array}{c}2 \text { Days } \\
\text { After 2nd. } R .\end{array}$ & $58 \%$ & 459 & 8,400 & $2,772(33.0 \%)$ & 0 & 0 & $5,628(67.0 \%)$ & $924(11.0 \%)$ & $294(3.5 \%)$ \\
\hline & $\begin{array}{c}3 \text { Days } \\
\text { After 2nd. R. }\end{array}$ & 一 & - & 12,900 & $6,708(52.0 \%)$ & $64(0.5 \%)$ & 0 & $6,128(47.5 \%)$ & $1,513(12.5 \%)$ & $323(2.5 \%)$ \\
\hline & $\begin{array}{l}\text { Before } \\
\text { 3rd. Reinject. }\end{array}$ & $61 \%$ & 450 & 4,400 & $2,244(51.0 \%)$ & 0 & 0 & $2,156(49.0 \%)$ & $22(0.5 \%)$ & 0 \\
\hline & $\begin{array}{c}1 \text { Day } \\
\text { After 3rd. } R .\end{array}$ & $60 \%$ & 502 & 4,200 & $1,029(24.5 \%)$ & 0 & 0 & $8,171(75.5 \%)$ & $315(7.5 \%)$ & $20(0.5 \%)$ \\
\hline & $\begin{array}{c}2 \text { Days } \\
\text { After 3rd. R. }\end{array}$ & $62 \%$ & 443 & 4,400 & $1,694(38.5 \%)$ & $66(1.5 \%)$ & $44(1.0 \%)$ & $2,596(59.0 \%)$ & $396(9.0 \%)$ & $88(2.0 \%)$ \\
\hline & $\begin{array}{c}3 \text { Days } \\
\text { After 3rd. } \mathrm{R} \text {. }\end{array}$ & $62 \%$ & 435 & 6,100 & $885(14.5 \%)$ & $30(0.5 \%)$ & 0 & $5,185(85.0 \%)$ & $336(5.5 \%)$ & 0 \\
\hline \multirow{12}{*}{460} & $\begin{array}{c}\text { Before } \\
\text { Sensitization }\end{array}$ & $70 \%$ & 544 & 4,900 & $882(18.0 \%)$ & $147(3.0 \%)$ & 0 & $3,871(79.0 \%)$ & 0 & 0 \\
\hline & $\begin{array}{c}\text { After } \\
\text { Sensitization }\end{array}$ & $57 \%$ & 443 & 9,300 & $1,256(13,5 \%)$ & $278(3.0 \%)$ & 0 & $7,766(83.5 \%)$ & $140(1.5 \%)$ & 0 \\
\hline & $\begin{array}{c}\text { Before } \\
\text { 1st. Reinject. }\end{array}$ & $61 \%$ & 520 & 7,200 & $2,592(36.0 \%)$ & $324(4.5 \%)$ & 0 & $4,284(59.5 \%)$ & 0 & 0 \\
\hline & $\begin{array}{c}1 \text { Day } \\
\text { After 1st. } R \text {. }\end{array}$ & $60 \%$ & 558 & 8,300 & $4,524(54.5 \%)$ & $165(2.0 \%)$ & 0 & $3,611(43.5 \%)$ & 0 & 0 \\
\hline & $\begin{array}{c}2 \text { Days } \\
\text { After lst. R. }\end{array}$ & $59 \%$ & 550 & 6,800 & $3,570(52.5 \%)$ & $102(1.5 \%)$ & 0 & $3,128(46.0 \%)$ & $34(0.5 \%)$ & 0 \\
\hline & $\begin{array}{r}1 \text { Day } \\
\text { After } 2 \text { 2nd. R. }\end{array}$ & $57 \%$ & 476 & 5,000 & $1,400(28.0 \%)$ & $50(1.0 \%)$ & $25(0.5 \%$ & $3,525(70.5 \%)$ & $325(6.5 \%)$ & $50(1.0 \%)$ \\
\hline & $\begin{array}{c}2 \text { Days } \\
\text { After 2nd. R. }\end{array}$ & $51 \%$ & 456 & 6,700 & $1,173(17.5 \%)$ & $200(3.0 \%)$ & 0 & $5,327(79.5 \%)$ & $1,206(18.0 \%)$ & $201(3.0 \%)$ \\
\hline & $\begin{array}{c}3 \text { Days } \\
\text { After } 2 \text { nd. } \mathrm{R} \text {. }\end{array}$ & - & - & 17,800 & $3.916(22.0 \%)$ & $801(4.5 \%)$ & 0 & $13,083(73.5 \%)$ & $1,513(13.5 \%)$ & $534(3.0 \%)$ \\
\hline & $\begin{array}{c}\text { Before } \\
\text { 3rd. Reinject. }\end{array}$ & $65 \%$ & 529 & 3,300 & $891(27.0 \%)$ & $33(1.0 \%)$ & 0 & $2,376(72.0 \%)$ & 0 & 0 \\
\hline & $\begin{array}{c}1 \text { Day } \\
\text { After 3rd. R. }\end{array}$ & $56 \%$ & 489 & 4,100 & $697(17.0 \%)$ & $61(1.5 \%)$ & 0 & $3,342(81.5 \%)$ & $328(8.0 \%)$ & $41(1.0 \%)$ \\
\hline & $\begin{array}{c}2 \text { Days } \\
\text { After 3rd. R. }\end{array}$ & $60 \%$ & 436 & 4,200 & $924(22.0 \%)$ & $84(2.0 \%)$ & 0 & $3,192(76.0 \%)$ & $294(7.0 \%)$ & 0 \\
\hline & $\begin{array}{c}3 \text { Days } \\
\text { After 3rd. R. }\end{array}$ & $63 \%$ & 431 & 5,800 & $1,914(33.0 \%)$ & $87(1.5 \%)$ & 0 & $3,799(65.5 \%)$ & $261(4.5 \%)$ & 0 \\
\hline
\end{tabular}




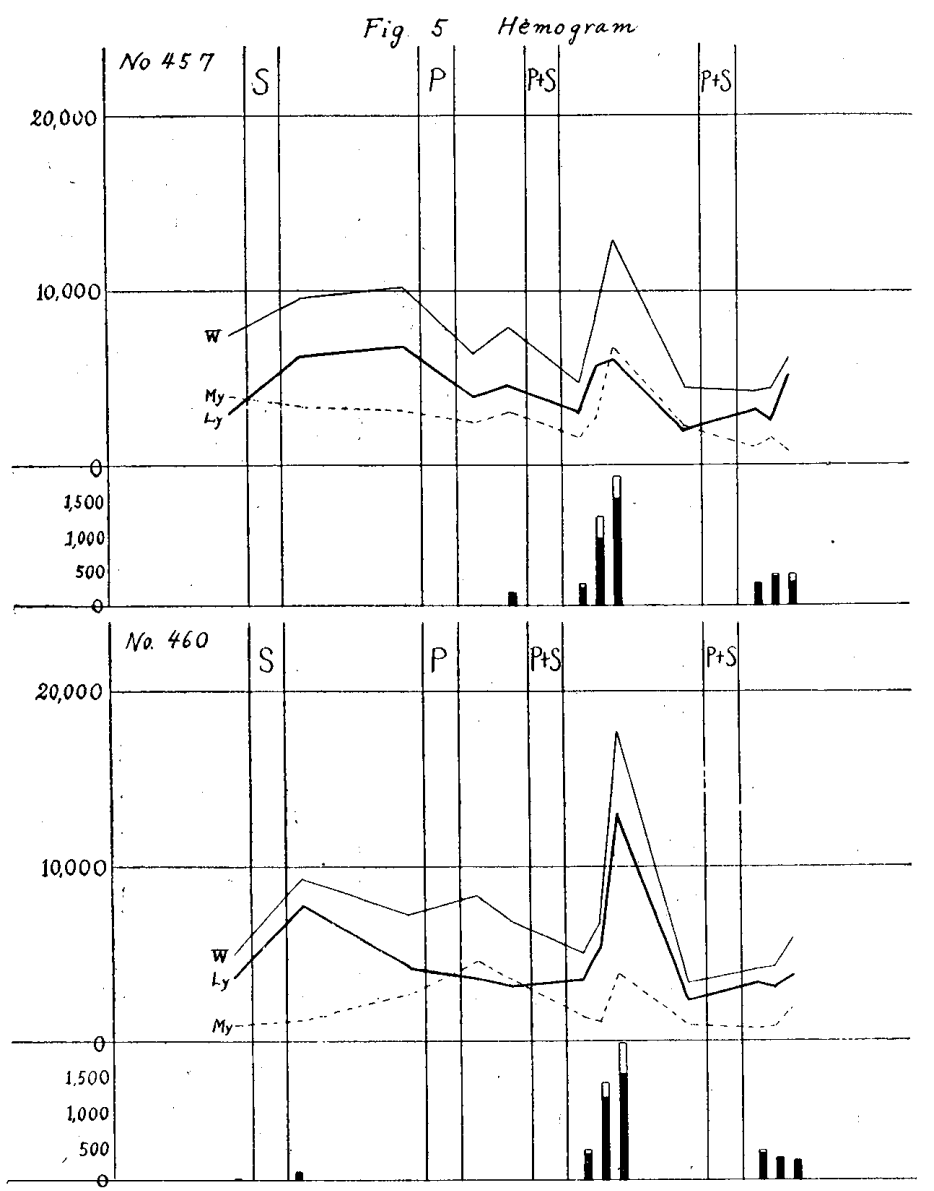

れる. この際第 2 回再注射の淋巴腺「未」加牛 血淸の影響はない.No.461 に就いて述ぶれ ば，牛血清感作後稍々多く，その時の白血球數 24,300の $8.5 \%$ 幼若淋巴球が出現するが淋巴 芽球の出現は見ない:この家秋は他の家東に比 して，血液像が動き易い傾向を有するものと考 觉られる。淋巴腺「木」加卵蛋白の再注射では 第 1 日 $1.5 \%$ ，第 2 日 $1.0 \%$ 幼若淋巴球が現 われるに過ぎず, 淋巴芽球は出現しない。然る に，淋巴腺「木」加牛血清の再々注射後に於て 第 1 日，その時の白血球數 5,700の $11.5 \%$ 幼 若淋巴球，5.5\%の淋巴芽球の出現を見，第 2 日 その時の白血球數 12,400 の $24.5 \%$ 幼若淋巴 球，9.0\%の淋巴芽球，第 3 日 $12,400 の 12.0 \%$ の幼若淋巴球, $2.0 \%$ の淋巴芽球の出現を見る. 即ら，No. 461 に於て西再々注射後リンホン・ アレルギーの惹起されたことを考皇させる．份 No.461 に於て再及注射後第 17 日に至り幼若 淋巴球は $1.5 \%$ に著減して淋巴芽球は出現しな くなつている．淋巴芽球の出現する時は變性像 を是するものを常に湿在している.

淋巴球數は TAPLE 11 死び Fig.6 に見る如 く, No. 458 に於ては淋巴腺「木」加牛血清を 注射した後にのみ絕對性又は相對性淋巴球霄多 を見，No. 461 に於ては牛血清感作によつて白

淋巴芽球が出現し，第 2 日 6,100の $14.0 \%$ 幼若淋巴 球，9\%の淋巴芽球方出現し，第 3 日 5,200の $13.0 \% の$ 幼若淋巴球，4\%の淋巴芽球が出現し，リンホン・アレ ルギーの惹起されたことる考党させる，更に，第2回再 注射後 3 週間を經て, 淋巴腺「木」加畉盆白を逨日 3 日 閒第 3 回再注射を行 5 に, 注射前白血球 3,700 の $1.0 \%$ の幼若淋巴球の出現に過ぎず，淋巴芽球の出現なきすの が，注射後第 1 日白血球數 4,000 の $9.0 \%$ 幼若淋巴球 出現， $0.5 \%$ の淋四芽球の出現を見，第 2 日白血球數 4,800の $10.5 \%$ 幼若淋巴球, $0.5 \%$ の淋巴芽球の出現を 見，第 3 日白血球數 5,100の $2.0 \%$ 幼若淋巴球， $1.0 \%$ の淋巴芽球の出現を見る. 即ち $\mathrm{P}+\mathrm{E}$ の注射によりリンホン・ アレルギーの惹起せられたのが 認められる.このリンホン・ア レルギー萀起の何故なるかは, 最初に牛血清のみで感作したる のに, 第 1 回再注射として淋巴 腺「木」加卵蛋白を注射したが 家鬼はこの淋巴腺「ホ」加畉蛋 毛によつても二重に感作されて いる狀態となり，第 3 區洅注射 前に於て淋巴腺「木」加畉蛋白 に對する抗體が相當量先產され てあつたのではないかと考えら
血球增多症 (Leukocytosis) を起しているが淋巴球，骨 髓性細胞共に平行的に管加し，やはり淋巴腺「木」加牛 血淸を注射した後にのみ淋巴球增多症を見ている.

傜好酸球，好酸球，好監基球，單球には著變を見な い. 形質細胞は No. 458 に於て丽々注射後第 2 日に 1.0 \%出現している. 有核赤血球は出現しない, 再々汒射後 輕度の多染性赤血球を見ているに過ぎない，赤血球數， 血色素值は共に感作媵，再注射後輕度に減少与る傾向が ある。

\section{第二次實驗小括}

著者は第一次實驗に引續き，第正群として，牛血淸の

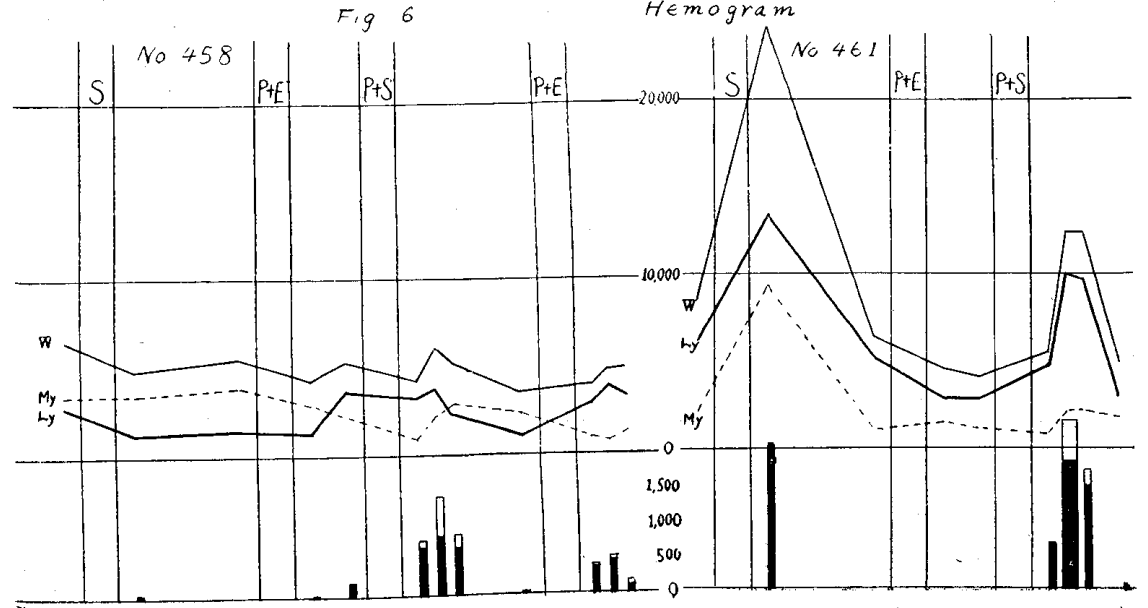


Tabis: 11 (4th Group)

\begin{tabular}{|c|c|c|c|c|c|c|c|c|c|c|}
\hline No. & & $\overline{\mathrm{Hb}}$ & $\mathrm{E}$ & $W$ & $\overline{\mathrm{M}} \mathrm{y}$ & Mon & $\mathrm{Pl}$ & Ly & JLy & Lybl \\
\hline \multirow{12}{*}{458} & $\begin{array}{c}\text { Before } \\
\text { Sensitization }\end{array}$ & $70 \%$ & 464 & 6,600 & $3,432(52.0 \%)$ & $198(3.0 \%)$ & $0(0 \%)$ & $2,970(45.0 \%)$ & $0(\quad 0 \%)$ & $0 \leq 0$ \\
\hline & $\begin{array}{c}\text { After } \\
\text { Sensitization }\end{array}$ & $5 \%$ & 363 & 4,800 & $3,456,72.0 \%$ & $0(0 \%$ & $0(0 \%)$ & $1,344(28.0 \%)$ & $48(1.0 \%)$ & $0(09$ \\
\hline & $\begin{array}{c}\text { Before } \\
\text { 1st. Reinject. }\end{array}$ & $58 \%$ & 431 & 5,500 & $3,987(72.5 \%)$ & $0(0 \%)$ & $0(0 \%)$ & $1,513(27.5 \%)$ & $0(0 \%)$ & $0(0)$ \\
\hline & $\begin{array}{c}1 \text { Day } \\
\text { After } 1 \text { st. R. }\end{array}$ & $55 \%$ & 378 & 4,200 & $2,814: 67$ & $42(1.0 \%)$ & $0(0 \%)$ & \%) & $21(0.5 \%)$ & $0(0)$ \\
\hline & $\begin{array}{c}2 \text { Days } \\
\text { After } 1 \text { st. R. }\end{array}$ & $56 \%$ & 395 & 5,300 & 2,275 & 185( & $0(0 \%$, & $\%)$ & $212(3.5 \%)$ & $0(0$ \\
\hline & $\begin{array}{r}1 \text { Day } \\
\text { After 2nd. R. }\end{array}$ & $56 \%$ & 368 & 4,200 & $945: 2$ & $21(0.5 \%)$ & $0(0 \%)$ & & 693 & 34 \\
\hline & $\begin{array}{c}2 \text { Days } \\
\text { After 2nd. R. }\end{array}$ & $56 \%$ & 359 & 6,100 & 2,07 & $122(2.0 \%)$ & $61(1.0 \%)$ & 3,8 & $854(14.0 \%)$ & $549(9.0$ \\
\hline & $\begin{array}{c}3 \text { Days } \\
\text { After 2nd. } \mathrm{R} \text {. }\end{array}$ & - & - & 5,200 & $2,808(54.0 \%)$ & $78(1.5 \%)$ & $0(0 \%)$ & 2,314 & $676(13.0 \%)$ & $208(4.0$ \\
\hline & $\begin{array}{ll} & \text { Before } \\
\text { III } & \text { Reinjection }\end{array}$ & $69 \%$ & 451 & 3,700 & $2,442(66.0 \%)$ & $37(1.0 \%)$ & $0(0 \%)$ & 1,221 & $37(1.0 \%)$ & $0(0)$ \\
\hline & $\begin{array}{l}1 \text { Day } \\
\text { After } \text { III Reinj. }\end{array}$ & $58 \%$ & 480 & 4,000 & 1,02 & $40(1.0 \%)$ & $0(0 \%)$ & & $9.0 \%)$ & $20(0.5)$ \\
\hline & $\begin{aligned} 2 & \text { Days } \\
\text { After } & \mathbb{I I} \text { Reinj. }\end{aligned}$ & $68 \%$ & 409 & 4,800 & $888(18$ & $48(1.0 \%)$ & $0(0 \%)$ & & $.5 \%$ & 2 \\
\hline & $\begin{aligned} & 3 \text { Days } \\
& \text { After } \text { II Reinj. } \\
&\end{aligned}$ & $66 \%$ & 410 & 0 & & $\%$ & $0(0 \%)$ & & $.0 \%)$ & $51 / 10$ \\
\hline \multirow{9}{*}{461} & $\begin{array}{c}\text { Before } \\
\text { Sensitization } \\
\end{array}$ & 8 & 675 & 8,600 & & $172(2.0 \%)$ & $0(0 \%)$ & & $0(0 \%)$ & $0 ? \quad 0$ \\
\hline & $\begin{array}{c}\text { After } \\
\text { Sensitization }\end{array}$ & $3 \%$ & 504 & 24,300 & 9,35 & $5 \%$ & $0(0 \%)$ & $0 \%$ & $2,066(8.5 \%)$ & 0( \\
\hline & $\begin{array}{c}\text { Before } \\
\text { 1st. Reinject. }\end{array}$ & $68 \%$ & 596 & 6,400 & 1, & $64 !$ & $0(0 \%)$ & & 0( & $0(0$ \\
\hline & $\begin{array}{c}1 \text { Day } \\
\text { After 1st. R. }\end{array}$ & $5 \%$ & 561 & 4,500 & 1,5 & $90(2.0 \%)$ & $0(0 \%)$ & $1 \%)$ & $68(1.5 \%)$ & $0: 0$ \\
\hline & $\begin{array}{c}2 \text { Days } \\
\text { After lst. R. }\end{array}$ & $68 \%$ & 588 & 4,100 & $\% ;$ & $102(2.5 \%)$ & $0(0 \%)$ & $.5 \%)$ & $41(1.0 \%)$ & $0(0)$ \\
\hline & $\begin{array}{c}1 \text { Day } \\
\text { After 2nd. R. }\end{array}$ & $57 \%$ & 517 & 5,700 & 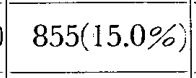 & $\%$ & $0(0 \%)$ & $\%$ & $.5 \%$ & $314(5.5$ \\
\hline & $\begin{array}{c}2 \text { Days } \\
\text { After 2nd. R. }\end{array}$ & $62 \%$ & 557 & 12 & 2, & $\%$ ) & $0(0 \%)$ & $\%)$ & 3,658 & 1,1 \\
\hline & $\begin{array}{c}3 \text { Days } \\
\text { After 2nd. R. }\end{array}$ & - & - & 12,400 & $2,294(18$ & $310(2.5 \%)$ & $0(0 \%)$ & $\%)$ & $1,488(12.0 \%)$ & $248(2$. \\
\hline & $\begin{array}{c}17 \text { Days } \\
\text { After 2nd. R. }\end{array}$ & $66 \%$ & 536 & 4,900 & $37.5 \%$; & $73,1.5 \%)$ & $0(0 \%)$ & $2,989(61.0 \%)$ & $74(1.5 \%)$ & $0, \quad 0 \%$ \\
\hline
\end{tabular}

みで連日 4 日間感作し，再注射を淋巴腺ホスファテイド のみによりて連日 3 日間行 万に，第一次實驗に於て述べ たようなアレルギー性變化は薏起せず，更にその第 1 回 再注射終了後第 3 日目より第 2 回再注射として浰巴腺木 スフテテイド加牛血清を連日 3 日間丽注射するに塗洙固 定染色末棑血液像に於て淋巴球系にアンルギー性變化の 若起せられているのを見る，更に第 2 回再注射後 3 週間 を經て第 3 回再注射として淋巴腺ホスファテイド加牛血 清を連日 3 日間再注射するに，矢張り末椎血液像に於て アレホギー性變化を認める. 第且群として感作は牛血 清，雨注射は淋巴腺「木小加畉蛋日にて行うに，第且群 に於けると同樣アレルギ一性變化は惹起せず，更にその 第 1 回再注射終了後第 3 日目より第 2 四再注射として淋 巴腺「木」加牛血淸を連日 3 日間再注射するに，第巩群 に於て述べたと略々同栐のアレルギー性變化を見た。 そ の主なる變化は次の如くである。

1 ，赤血球系には特記すべき何等の變化はみられない。
血液像に於ても，赤血球系骨髓系，白血球又は單球系に は著戀なく，殿質細胞が時に出現するのを認めた。

2. 淋巴球系にあつては，アレルギー性變化を焤起せる 場合には幼若淋巴球の多數仙現，並びに淋巴芽球庆び所 詆戀倠淋巴芽球の出現を又とめ大。

上記の實驗成績並に第一次富驗成績を綜合して考兄る に次の如き分析が可能であると考兄られる。

A. 牛血淸の感作に對して淋巴腺「木」加牛血淸の再注 射ではアレルギー性變化が淋巴球柔に惹起される. 然る に牛血清のみの再注射では縞化は殆んぞ起らない（第 一次實驗）更に淋巴腺「木」のみの再注射でも變化は起 らない，又淋巴腺「ホ」加畉蛋白の再注射でも戀化は起 らない（第二次實驗）

B. 牛血清感作, 第 1 回再注射牛血清のみ，それに引續 き第 2 回再注射淋巴腺「木」加牛血清ではその第 2 回侢 注射後變化は起らない(第一次實驗)然るに牛血清感作, 第 1 回再注射淋巴腺「木」の久或は淋巴腺「木」加甽蛋 
当，去れに引續き第2 回邽注射淋巴腺「ホ」加牛血清で

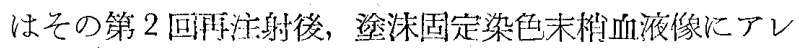

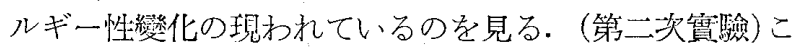

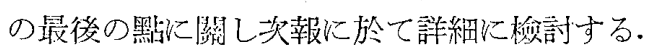

C. 淋巴腺ホ加牛血清の注射後約 3 週間定經て同じ淋巴 腺「ホ」加牛血清を再注射するにリンフン・アレルギー-

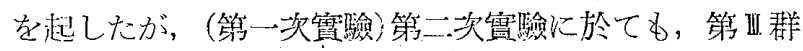
に於て䊩巴腺「木」加牛血清の注射後約 3 週安經て同じ 淋世腺「ホ」加牛血清老膊注射するに末秒血液像でアレ

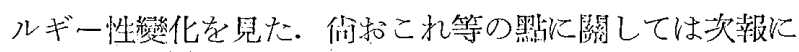

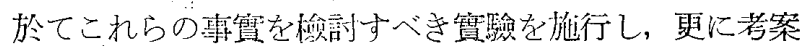
を重初て結論する等である。

\section{References}

1) Rosenau, M. J. and J. F. Anderson, Hyg. Lab. Bull. 29, U. S. Pub. Health Service, 1906.

2) Wells, H. G., The Chemical Aspects of Immunity, 2nd ed. New York, 1929.

3) Boyd, Fundamentals of Immunology, 1943.
4) Seegal, Agents of Diseasé and Host Resistence, by Gay and Associates, 1935.

5) Scott, W. M., J. Path. Bact. 14: 147, 1909.

6) Scott, W. M., J. Path. Bact. 15: 31, 1910.

7) Schultz, W. H. and Jordan. H. E., J. of pharmacol, and exp. therap. 11: 1911, 375.

8) Dale, H. H., J. of pharmacol. and exp. therap. IV, 1912-13, 167.

9) Friedberger und Mita, Zeit. Immunität. 10:362, 1911.

10) Wells, J. Inf. Dis. 9: 147, 1911.

11) Weil, J. Immunol.2: 525, 1917.

12) Tillet, Avery and Goebel, J. Exp. Med. 52: 347, 1930.

13) Hattori, Y. and Kumagai, N., Acta Haemat. Jap. 12: 13, Showa 24.

14) Miyata, K., Seiikai Zasshi 60: 684, Showa 16 ; 61: 625, Showa 17.

From the Third Medical Clinic of Kyoto University (Director: Professor M. Maekawa, M. D.)

\title{
Clinical and Experimental Study on Venous Return VII \\ On the Relationship Between Cardiac Systole and \\ Venous Return in Mitral Failure
}

BY

Manabu Takashima

(Received for Publication, Nov: 22, 195j)

\author{
静脈還流に關する臨店的並に禩驗的研究

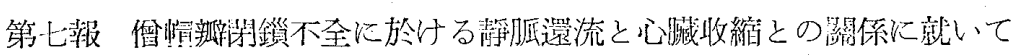

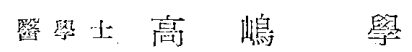

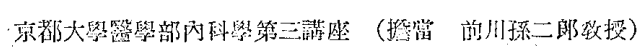

The author obtained the left auricular curves in 2 patients of mitral failure.

1) The wave obtained from lower part of left auriculus is interesting in that there is peculiar positive wave immediately after. Vs-wave due to the modification of venous return by blood-regurgitation during the ventricular contraction.

\section{緒言}

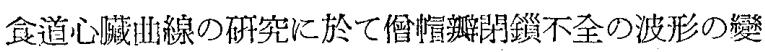

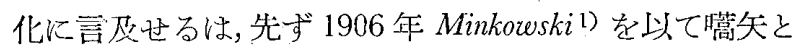
寸る. 次で Rautenberg2) は代儥期に食道心房业線に健康 心のそれと特に畦る變化を認めず，代償不全期に於て心

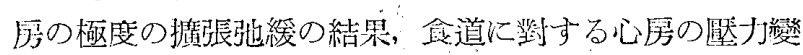

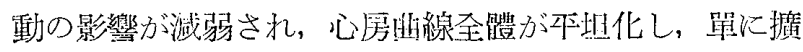
張初期即ち心空への血液流沂時の容皘變化のみが線に

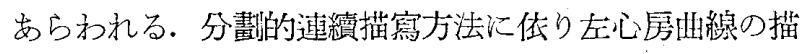

2) Severe damage of the mitral valves gives rise to large and long positive wave, while other waves decrease their amplitude.

3) Early in the diastolic phase a peculiar negative wave takes place due to the abrupt decrease of auricular blood volume.

寫範園の著しい腐大を認め, 彼は曲線の湸斷上の㵋值は

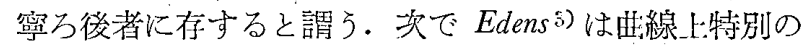

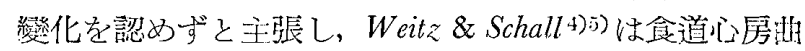

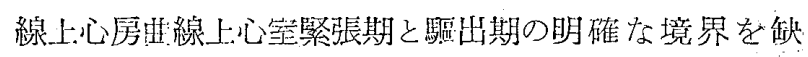
き，收䌉期检稚音の小振動々第 2 心音の振動の境界も办

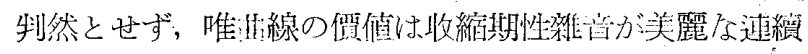

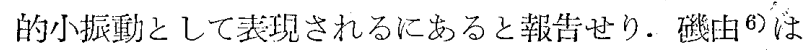
代貸機能完全なる際は $\mathrm{a}$ 波颇る䓔明にして $\mathrm{c}$ 棘（驅出期 の始り定示す）は此較的小なり，代筫機能轼度に障碍さ 